\title{
Jan Paweł II i Polska w wybranych przemówieniach prezydentów Stanów Zjednoczonych Ameryki: George'a Walkera Busha i Donalda Johna Trumpa
}

\author{
John Paul II and Poland in Selected Speeches of \\ the Presidents of the United States of America: \\ Georg Walker Bush and Donald John Trump
}

\section{Abstrakt}

Celem artykułu jest prezentacja percepcji osoby papieża Jana Pawła II i Polski z perspektywy prezydentów Stanów Zjednoczonych Ameryki. Jest ona tym bardziej interesująca, że owi prezydenci, przemawiający publicznie podczas różnych okazji, nie byli katolikami. Podstawowym źródłem artykułu są dwa oficjalne przemówienia prezydentów George'a W. Busha i Donalda J. Trumpa, pochodzące z archiwum prezydentów Stanów Zjednoczonych w Waszyngtonie. Przemówienia zostały dobrane ze względu na tematykę dotyczącą narodu polskiego i jego najwybitniejszego przedstawiciela w tysiącletniej historii - Jana Pawła II. Okazją do przemówienia G.W. Busha było poświęcenie Centrum Kulturalnego im. Papieża Jana Pawła II w Waszyngtonie (22 marca 2001), natomiast przemówienie D. Trumpa 
zostało wygłoszone przed Pomnikiem Powstania Warszawskiego, na Placu Krasińskich w Warszawie (8 lipca 2017), przy okazji wizyty w Polsce. Na literaturę przedmiotu składają się publikacje służące charakterystyce sylwetek wybranych prezydentów Stanów Zjednoczonych, a także publikacje z zakresu retoryki. Podstawową metodą badawczą była analiza jakościowa wybranych tekstów źródłowych. W celu lepszego ich zrozumienia, najpierw w zwięzły sposób zaprezentowane zostały wybrane elementy biografii autorów przemówień. W dalszej kolejności przeanalizowane zostały okoliczności, w jakich zostały wygłoszone wybrane mowy. Zastosowana metoda pozwoliła wydobyć charakterystyki papieża z Polski oraz narodu polskiego dokonane z perspektywy prezydentów Stanów Zjednoczonych. W percepcji G.W. Busha papież z Polski jest jedną z najciekawszych postaci w historii ludzkości. Do najbardziej znaczących epizodów pontyfikatu zaliczone zostały: pielgrzymka do Ojczyzny w 1979 roku, wizyta w Manili na Filipinach w 1995 roku, bezprecedensowa wizyta w synagodze i kraju muzułmańskim, przebaczenie okazane niedoszłemu zamachowcowi - Alemu Ağcy, oraz wizyty w Stanach Zjednoczonych, podczas których papież z Polski przypominał o godności człowieka i cnotach sprawiedliwego społeczeństwa. Z kolei w percepcji D. Trumpa na szczególne wyróżnienie zasłużył duch polskiego narodu, który znalazł wyraz w niezłomnej walce o zachowanie tożsamości kulturowej, pomimo utraty Ojczyzny i doświadczenia eksterminacji ze strony niemieckich nazistów i sowieckich komunistów. Ponadto na przykładzie przeobrażeń w Polsce i Europie, zapoczątkowanych pielgrzymką Jana Pawła II do Ojczyzny w 1979 roku, uwypuklony został wpływ wiary w Boga na przemiany polityczne i społeczne w świecie oraz na przetrwanie cywilizacji zachodniej opartej na wierze w Boga i na zachowaniu rodziny i wolności.

Słowa klucze: G.W. Bush, D.J. Trump, Jan Paweł II, Polska, przemówienie

\begin{abstract}
The article deals with the perception of the Pope John Paul II and Poland in the two speeches of the Presidents of the United States of America. The George W. Bush's speech given on the occasion of the dedication of the Pope John Paul II Cultural Center in Washington DC on March 22, 2001 and the Donald Trump's speech delivered in front of the Warsaw Uprising Monument on the Krasinski Square in Warsaw on July 8, 2017 were used as the sources for the study. The former speech is a laudation in honor of the Pope from Poland, whose biography was considered by the 43rd President of the United States as one of the most interesting in human history. Among the most notable episodes of the pontificate, George W. Bush listed the 1979 pilgrimage to his homeland, the 1995 visit to Manila in Philippines, the unprecedented visits to a synagogue and a Muslim country, the forgiveness shown to Ali
\end{abstract}


Ağca - the would-be assassin, and the visits to the United States during which the Pope from Poland reminded the people of human dignity and the virtues of a just society. The latter speech is a laudation on the spirit of the Polish nation. Donald Trump emphasized the steadfastness of the Poles in the struggle to preserve their cultural identity despite the loss of their homeland. He recalled the period of partition and extermination of the Polish nation by the German Nazis and the Soviet Communists during World War II. The 45th President of the United States reminded the world about famous Poles: Nicolaus Copernicus, Frederic Chopin, Casimir Pulaski, Thaddeus Kosciuszko and Saint John Paul II. He also spoke about the lasting ties between the Americans and the Poles and about the common values cherished on both sides of the Atlantic. On the example of social transformations in Poland and Europe initiated by John Paul II's pilgrimage to Poland in 1979, Donald Trump emphasized the influence of faith in God on political and social transformations in the world. He also expressed hope for the survival of Western civilization based on faith in God and the preservation of family and freedom.

Keywords: G.W. Bush, D.J. Trump, John Paul II, Poland, speech

\section{Wstęp}

Istnieją mowy, które kształtują historię, i historie, które utrwalane są w przemówieniach. W nich kultywowana jest pamięć o dziedzictwie ludzkości' ${ }^{1}$ Niektóre przemówienia umacniają tożsamość narodów i tworzą relacje międzynarodowe, sprzyjają pojednaniu i kształtują przyszłość ${ }^{2}$. Szczególne znaczenie mają doniosłe przemówienia światowych przywódców politycznych i liderów duchowych. Nierzadko jedni oddziałują na drugich. Wśród wielkich mówców ludzkiej historii nie można pominąć Jana Pawła II.

Zrozumiała jest atencja, jaką Polacy darzą swego rodaka, Jana Pawła II, jedynego papieża wywodzącego się z polskiego narodu. Ponieważ jego oddziaływanie miało charakter globalny, interesujące będzie przyjrzeć się percepcji osoby i dokonań Jana Pawła II oraz historii polskiego narodu przez prezydentów Stanów Zjednoczonych Ameryki jako kraju, który jest liderem światowej polityki i kultury.

1 Vide: Wielkie mowy historii, t. 1-4, red. Marek Gumkowski (Warszawa: Wydawnictwo Polityka, 2006).

2 Walter J. Burghardt, Preaching. The Art and the Craft (New York-Mahwah: Paulist Press, 1987), 6. 
Podstawowym źródłem dla niniejszego opracowania są mowy dwóch prezydentów George’a Walkera Busha i Donalda Johna Trumpa, zaczerpnięte $\mathrm{z}$ archiwum Białego Domu w Waszyngtonie $e^{3}$. O doborze przemówień zadecydowała ich treść dotycząca w całości przede wszystkim Jana Pawła II bądź polskiego narodu. Najpierw zwięźle zaprezentujemy sylwetki tych dwóch prezydentów, a następnie omówimy kolejno okoliczności i główny temat wybranych przemówień, by w ostatecznym podsumowaniu ukazać obraz Jana Pawła II i Polski z perspektywy przywódców Stanów Zjednoczonych.

\section{Zwięzła prezentacja prezydentów Stanów Zjednoczonych Ameryki: George'a Walkera Busha i Donalda Johna Trumpa}

Autorzy interesujących nas przemówień, prezydenci: George W. Bush i Donald J. Trump, otrzymali nominację na najwyższy urząd w państwie ze strony partii republikańskiej. Oprócz reprezentacji partyjnej, łączy ich ten sam wiek - są rówieśnikami urodzonymi w 1946 roku.

\section{George W. Bush}

George Walker Bush ma swoje miejsce w historii jako 43. prezydent Stanów Zjednoczonych. Pełnił ten urząd w latach 2001-2009. G.W. Bush jest synem George’a Herberta Walkera Busha (1924-2018), który był 41. prezydentem tego kraju w latach 1989-1993. G.W. Bush ukończył studia na Yale University i Harvard Business School, gdzie uzyskał stopień magistra (MBA). W latach siedemdziesiątych XX wieku zajmował się przemysłem naftowym w Teksasie, pełniąc kierownicze stanowiska w przedsiębiorstwach. W latach 1995-2000 był gubernatorem Teksasu. Podczas swych dwóch kadencji prezydenckich trzy razy odwiedził Polskę, dwa razy za kadencji prezydenta Aleksandra Kwaśniewskiego (2001 i 2003 r.) i raz za kadencji Lecha Kaczyńskiego (2007 r.). Jeśli chodzi o wyznanie, jest chrześcijaninem należącym do Kościoła metodystycznego. Deklaruje się jako człowiek głęboko wierzący. Dzięki nawróceniu religijnemu

3 George W. Bush, Selected Speeches of President George W. Bush 2001-2008, 37-39, https://georgewbush-whitehouse.archives.gov/infocus/bushrecord/documents/Selected_Speeches_George_W_Bush.pdf (dostęp: 27.10.2020); Donald J. Trump, Remarks by President Trump to the People of Poland (July 6, 2017), https://www.whitehouse.gov/ the-press-office/2017/07/06/remarks-president-trump-people-poland-july-6-2017 (dostęp: 27.10.2020); https://trumpwhitehouse.archives.gov/briefings-statements/ remarks-president-trump-people-poland/ (dostęp: 8.04.2021). 
pokonał uzależnienie od alkoholu. W kwietniu 2008 roku przyjął u siebie w Białym Domu papieża Benedykta XVI (2005-2013) $)^{4}$. Po zakończeniu kadencji prezydenckiej zajął się malarstwem i pisaniem książek. Wydał między innymi książkę pt. Portraits of Courage: A Commander in Chief's Tribute to America’s Warriors ${ }^{5}$, w której zamieścił kolekcję kopii 66 obrazów olejnych i 4 murali panelowych oraz opowiadania upamiętniające amerykańskich weteranów wojennych, których poznał osobiście. Ponadto napisał autobiografię zatytułowaną Decision Points ${ }^{6}$ oraz biografię swojego ojca, wydaną pod tytułem A Portrait of My Father ${ }^{7}$. Ostatnio zaś wydał album, zawierający czterdzieści trzy portrety imigrantów ${ }^{8}$.

George W. Bush bardzo cenił Jana Pawła II, o czym między innymi świadczy jego wzruszające przemówienie podczas uroczystości nadania nazwy Centrum Kulturalnemu Jana Pawła II w Waszyngtonie w dniu 22 marca 2001 roku. Mimo szacunku, czy wręcz fascynacji Janem Pawłem II, G.W. Bush zdecydowanie różnił się z nim w kwestii wojny w Iraku: Jan Paweł II był jej zdecydowanym przeciwnikiem, ostrzegając, że łatwo ją rozpocząć, ale trudno zakończyć. Mimo tych przestróg, G.W. Bush zorganizował koalicję państw i w marcu 2003 roku dokonał inwazji na Irak9.

\section{Donald J. Trump}

Drugi z interesujących nas prezydentów, Donald John Trump, urodził się i wychował w nowojorskiej dzielnicy Queens. W roku 1968 uzyskał dyplom z ekonomii w szkole biznesu na Uniwersytecie Pensylwanii w Filadelfii (Wharton School of Business). Karierę biznesową rozpoczął w 1971 roku od przejęcia firmy rodzinnej. Zajmował się remontowaniem nieruchomości mieszkaniowych i komercyjnych, a także zarządzaniem hotelami, kasynami i polami golfowymi w różnych krajach świata. Przez

4 Brian Duignan, George W. Bush, president of the United States, https://www.britannica. com/biography/George-W-Bush/Presidency (dostęp: 10.10.2020). G.W. Bush mianował dwóch sędziów Sądu Najwyższego: J. Robertsa i S. Alito.

5 George W. Bush, Portraits of Courage: A Commander in Chief's Tribute to America's Warriors (New York: Random House, 2017).

6 Idem, Decision Points (New York: Random House, 2010).

7 Idem, A Portrait of My Father (New York: Random House, 2014); Office of George W. Bush: https://www.georgewbush.com/ (dostęp:10.10.2020).

8 George W. Bush, Out of Many, One: Portraits of America's Immigrants (New York: Crown Publishing Group, 2021).

9 Vide: Ignacy Masny, Jan Paweł II wobec wojny w Iraku w 2003 r., https://jp2online. $\mathrm{pl} /$ publikacja/john-paul-ii-on-the-2003-iraq-war;UHVibGljYXRpb246OTg= (dostęp: 2.10.2021). 
dwadzieścia lat (1996-2015) D.J. Trump organizował konkursy Miss Universe, Miss USA i Miss Teen USA. W okresie od 2004 do 2015 roku prowadził w telewizji NBC program zatytułowany „Uczeń” (The Apprentice). Jako multimiliarder jest od wielu lat uwzględniany przez dwutygodnik „Forbes” w rankingu najbogatszych ludzi świata. 9 listopada 2016 roku odniósł zwycięstwo w wyborach nad Hillary Clinton, przedstawicielką Partii Demokratycznej, po czym 20 stycznia 2017 roku został zaprzysiężony jako 45. prezydent Stanów Zjednoczonych. D.J. Trump objął to stanowisko jako najstarszy, ponad siedemdziesięcioletni, a zarazem najbogatszy prezydent w historii Stanów Zjednoczonych ${ }^{10}$.

Pytany o przynależność religijną, Donald Trump deklarował się pierwotnie jako członek Kościoła prezbiteriańskiego. Przyznawał, że rodzice przekazali mu wiarę chrześcijańską i nauczyli modlitwy. Potem deklarował się jako człowiek wierzący w Boga, ale bezwyznaniowy. Według sondażu przeprowadzonego na początku października 2020 roku przez „Real Clear Politics”, Trump był bardzo popularny wśród wyborców należących do chrześcijańskich wspólnot ewangelikalnych, zyskując wśród nich $81 \%$ poparcia ${ }^{11}$. 24 maja 2017 roku spotkał się z papieżem Franciszkiem w Watykanie, ale ich poglądy społeczne mocno się różniły, zwłaszcza w kwestii migrantów. Trump zarządził budowę muru na granicy Stanów Zjednoczonych z Meksykiem, a Franciszek był przeciwnikiem wznoszenia murów między ludźmi, proponując zamiast nich - mosty ${ }^{12}$.

Gdy chodzi o Polskę, 45. prezydent Stanów Zjednoczonych stawiał ją jako wzór członka paktu północnoatlantyckiego NATO, który wypełnia zobowiązania finansowe wobec paktu. Był też wdzięczny za poparcie, jakie zyskał w wyborach od licznych Polaków, będących obywatelami Stanów Zjednoczonych ${ }^{13}$.

10 Vide: Brian Duignan, Donald Trump, president of the United States, https://www.britannica.com/biography/Donald-Trump (dostęp: 10.10.2020).

11 US-Ordensfrauen bei Trump-Wahlkampf in Ohio, http://kath.net/news/73242 (dostęp: 26.10.2020).

12 Podczas swojej kadencji D. Trump nominował troje członków dziewięcioosobowego Sądu Najwyższego. Zostali nimi: N. Gorsuch, B. Kavanaugh i A. Barrett, Amy Coney Barrett ist US-Verfassungsrichterin! - Senat bestätigt die Kandidatin, http://kath.net/ news/73255 (dostęp: 27.10.2020); Supreme Court of the United States. Current Members, https://www.supremecourt.gov/about/biographies.aspx (dostęp: 27.10.2020).

13 Duignan, Donald Trump... 


\section{Przemówienie G.W. Busha w Waszyngtonie (22 marca 2001)}

Po krótkiej prezentacji autorów sławnych przemówień, możemy poddać analizie same teksty źródłowe, czyli przemówienie G.W. Busha z okazji poświęcenia Centrum Kultury Papieża Jana Pawła II w Waszyngtonie z 22 marca 2001 roku, oraz przemówienie Donalda Trumpa przed Pomnikiem Powstania Warszawskiego, na placu Krasińskich w Warszawie w dniu 8 lipca 2017 roku. Pierwsze jest laudacją na cześć najsławniejszego Polaka w tysiącletniej historii narodu, drugie - laudacją na cześć narodu o tysiącletniej tradycji. W oryginalnej anglojęzycznej wersji tekst pierwszego wystąpienia liczy 1086 wyrazów, a tekst drugiego - 3625 wyrazów, zaś wraz z komentarzami dotyczącymi aplauzu oraz okrzykami audytorium - 3737 wyrazów.

\section{Okoliczności przemówienia}

Okazją do przemówienia G.W. Busha było poświęcenie Centrum Kultury Papieża Jana Pawła II w Waszyngtonie, stolicy Stanów Zjednoczonych. Wspomniane centrum to muzeum prezentujące wystawy na temat wiary i duchowości, a także instytut badawczy poświęcony myśli i działalności papieża z Polski. Inspiracji do powstania tego centrum dostarczyło spotkanie Jana Pawła II z biskupem amerykańskim polskiego pochodzenia, Adamem Maidą, w 1989 roku. Budowę zaczęto w 1997 roku, a poświęcenie odbyło się 22 marca 2001 roku, dwa miesiące po objęciu urzędu prezydenta przez G.W. Busha. Centrum znajduje się nieopodal Katolickiego Uniwersytetu Ameryki i Narodowej Bazyliki Niepokalanego Poczęcia. Od 2011 roku jest ono własnością Rycerzy Kolumba i funkcjonuje jako Narodowe Sanktuarium św. Jana Pawła II ${ }^{14}$. Upamiętnia ono i popularyzuje wśród społeczności amerykańskiej osobę i nauczanie papieża Polaka.

\section{Główny temat - laudacja na cześć Jana Pawła II}

G.W. Bush rozpoczął przemówienie od żartu. Powiedział, że mama nadal mówi mu, co ma robić, a on na ogół jej słucha. Następnie zastosował zwroty adresatywne skierowane do obecnych kardynałów: Adama

14 Saint John Paul II National Shrine. Plan Your Pilgrimage, https://www.jp2shrine.org/ jps/en/resources/plan-your-pilgrimage-booklet.pdf (dostęp: 9.07.2020). 
Maidy, Edmunda Szoki i Teodora McCarricka ${ }^{15}$. W adresie do tego ostatniego ponownie wykorzystał humor: pogratulował godności kardynalskiej, stosując porównanie: „Chociaż obydwaj otrzymaliśmy nowe zadania, ale tylko ja otrzymałem je na ograniczony czas"16. Historia pokazała, że również godność kardynalska McCarricka okazała się tymczasowa ${ }^{17}$.

Po grzecznościowym wstępie prezydent G.W. Bush wspomniał wizytę kard. Karola Wojtyły na Katolickim Uniwersytecie Ameryki w 1976 roku i wspomniał, że po pierwszym błogosławieństwie Jana Pawła na placu św. Piotra, jeden z dziennikarzy skomentował: „To nie jest Papież z Polski, to jest Papież z Galilei”. Zdaniem G.W. Busha, „Od tamtego dnia aż po dzisiejszy, życie papieża napisało jedno z najbardziej inspirujących opowiadań naszych czasów”18. Wśród najważniejszych epizodów tego opowiadania prezydent Bush wymienił najpierw pierwszą pielgrzymkę papieża do Ojczyzny w 1979 roku, „gdy wiara przekształciła się w opór i rozpoczęła szybki upadek imperium komunistycznego. Łagodny, młody kapłan, niegdyś zmuszony przez nazistów do przymusowej pracy, stał się wrogiem tyranii i świadkiem nadziei”'19. Nawet ostatni przywódca ateistycznego Związku Radzieckiego, Michał Gorbaczow, uznał w papieżu najwyższy autorytet moralny na Ziemi.

Następny epizod to wizyta papieża w Manili w 1995 roku, gdzie Jan Paweł II przemawiał do największej w historii ludzkości, pięciomilionowej grupy słuchaczy. G.W. Bush znakomicie posłużył się kontrastem: przypomniał, że jako młody kapłan Wojtyła podróżował wozem konnym, by uczyć dzieci w małych wioskach, pięćdziesiąt lat później ucałował ziemię 123 krajów i uczył miliardy ludzi. Inną ważną treścią życia Jana Pawła II, znaczącą dla historii, była - zdaniem G.W. Busha - misja pojednania i wzajemnego poszanowania pomiędzy chrześcijanami, żydami i muzułmanami. Jan Paweł II był „pierwszym współczesnym papieżem, który wszedł do synagogi i odwiedził kraj muzułmański. Zawsze łączy

15 O roli wstępu w przemówieniu por. Cz. Jaroszyński, P. Jaroszyński, Kultura słowa. Podstawy retoryki klasycznej (Szczecinek: Fundacja Nasza Przyszłość, 2008), 60-62.

Bush, Selected Speeches, 37.

17 Theodore Edgar McCarrick (1930-) został wyniesiony do godności kardynalskiej 21 lutego 2001 r., 16 maja 2006 r. przeszedł na emeryturę, 28 lipca 2018 r. zrezygnował z godności kardynalskiej, 13 lutego 2019 r. został przeniesiony do stanu świeckiego, http://www.catholic-hierarchy.org/bishop/bmccar.html (dostęp: 9.07.2020).

18 Bush, Selected Speeches, 37.

19 Ibidem. Można się tu dopatrzyć nawiązania do tytułu biografii Jana Pawła II napisanej przez G. Weigela, Świadek nadziei. Biografia papieża Jana Pawła II (Kraków: Znak, 2005). 
praktykę tolerancji z pasją dla prawdy"20. Szczególnym, wspomnianym przez amerykańskiego prezydenta symbolem pojednania między ludźmi i przykładem przebaczenia $\mathrm{w}$ odpowiedzi na przemoc były papieskie odwiedziny zamachowcy Alego Ağcy w więzieniu.

Wśród ważnych dokonań Jana Pawła II prezydent USA wymienił orędzie wyzwolenia niesione do każdego zakątka świata. G.W. Bush wykorzystał kontrast, ukazując troskę papieża tak o biednych, jak i bogatych. Biednym i chorym niósł orędzie solidarności z ich cierpieniem i zapewnienie, że jeśli nawet są zapomniani przez ludzi, to nie przez Boga. Bogatym natomiast przypominał, że bogactwo samo w sobie stanowi fałszywą wygodę, a dobra świata są niczym bez dobroci ${ }^{21}$.

G.W. Bush przypomniał nauczanie Jana Pawła II podczas czterech pielgrzymek do Ameryki na temat wolności i odpowiedzialności oraz sprawiedliwego społeczeństwa, w którym wszyscy są szanowani i otoczeni opieką. Zdaniem amerykańskiego prezydenta, Jan Paweł II nigdy nie mówił tak przekonywająco jak wówczas, gdy opowiadał się za kulturą życia na wszystkich jego etapach.

W podsumowaniu obrazowego przemówienia G.W. Bush wyraził wdzięczność za to, że Jan Paweł II wybrał Waszyngton na miejsce dla centrum kultury i za to, że „Miejsce to upomina się o godność ludzkiej osoby, wartość każdego życia i blask prawdy"22.

W zakończeniu przemówienia znalazły się wyrazy wdzięczności za orędzie głoszone przez Jana Pawła II oraz za jego osobę jako orędownika o prorockiej sile i dobrym poczuciu humoru, i za to, że zawsze kieruje ludzi w stronę rzeczy trwałych i miłości, która zbawia ${ }^{23}$.

\section{Przemówienie D. Trumpa przed Pomnikiem Powstania Warszawskiego na placu Krasińskich w Warszawie (6 lipca 2017)}

\section{Okoliczności przemówienia}

Drugie z interesujących nas przemówień zostało wygłoszone przez D. Trumpa, który gościł w Polsce w pierwszym roku swego urzędowania, w dniach 5-6 lipca 2017 roku. Okazją do tej dwudniowej wizyty

20 Bush, Selected Speeches, 37-38.

21 Ibidem, 38.

22 Ibidem, 39.

23 Ibidem. 
amerykańskiego prezydenta był odbywający się w Warszawie szczyt państw Trójmorza, rokujący nadzieję na poszerzenie współpracy tego regionu z Ameryką. Polska jako gospodarz spotkania i największy kraj regionu została bardzo dowartościowana przez amerykańskiego prezydenta w podniosłym przemówieniu ${ }^{24}$.

\section{Główny temat - historia Polski oczami prezydenta Stanów Zjednoczonych Ameryki}

Wystąpienie D. Trumpa w Warszawie rozpoczęło się od ingracjacji, czyli zwrotów miłych dla słuchaczy wypowiadanych w celu pozyskania, od samego początku, ich życzliwości (łac. captatio benevolentiae) ${ }^{25}$. Sedno przesłania do polskiego narodu zostało ujęte w sformułowaniu: „Ameryka uwielbia Polskę, Ameryka kocha Polaków”26. W uzasadnieniu prezydent Trump wyjaśnił, że Polacy dokonali wiele dla swojego regionu geopolitycznego, a ponadto jako emigranci, a potem jako Amerykanie polskiego pochodzenia bardzo wzbogacili Stany Zjednoczone. W konwencji ingracjacji utrzymane były również dalsze fragmenty przemówienia, w których D. Trump mówił, że jest zachwycony Polską, wspaniałym krajem w geograficznym sercu Europy, wielkim narodem o ponadtysiącletniej historii, posiadającym duchową siłę ${ }^{27}$.

Po retorycznym wstępie prezydent Trump nawiązał do genius loci - pomnika Powstania Warszawskiego, przed którym przemawiał. Ważną część przemówienia stanowiło uwypuklenie bohaterstwa żołnierzy polskich walczących z niemieckim okupantem, przy jednoczesnej obojętności i wyczekiwaniu Armii Czerwonej na to, by Polacy się wykrwawili. Amerykański prezydent przytoczył statystyki, wskazując, iż pomnik przypomina o 150 tys. Polaków, którzy zginęli w straceńczej walce z uciskiem. Cytując słowa biskupa męczennika Michała Kozala: „Od przegranej orężnej bardziej przeraża upadek ducha u ludzi”, Trump,

24 Duignan, Donald Trump...

25 M. Korolko, Sztuka retoryki. Przewodnik encyklopedyczny (Warszawa: Wiedza Powszechna, 1990), 79-81.

26 Donald J. Trump, Remarks by President Trump to the People of Poland (July 6, 2017), https://www.whitehouse.gov/the-press-office/2017/07/06/remarks-president-trump-people-poland-july-6-2017 (dostęp: 27.10.2020). Przemówienie zaczerpnięte jest z przytoczonej powyżej strony internetowej pozbawionej podziału na strony.

27 Jakże kontrastowo brzmią słowa amerykańskiego prezydenta do tych, które wypowiadał o Polsce Władysław Bartoszewski ,jako brzydkiej pannie bez posagu, której pozostaje się tylko uśmiechać, by zyskać sympatię innych" - Ryszard Legutko, Antykaczyzm (Kraków: Wydawnictwo M, 2013), 114. 
na przykładzie Polaków, podkreślił znaczenie kultywacji szlachetnego ducha $w$ narodzie.

Oprócz wątków historycznych i lokalnych prezydent USA uwzględnił też genius temporis - spotkanie z politykami reprezentującymi kraje Trójmorza, i zaznaczył, że Ameryka będzie chętnie pogłębiać partnerstwo i wymianę handlową z rozwijającymi się gospodarkami regionu, a zarazem pomoże w zapewnieniu dostępu „do alternatywnych źródeł energii, aby Polska i jej sąsiedzi nigdy więcej nie stali się zakładnikiem jedynego dostawcy energii”. Po tym krótkim nawiązaniu do okoliczności spotkania, D. Trump kontynuował istotny temat swego przemówienia, jakim była bohaterska historia zmagań polskiego narodu o zachowanie tożsamości pomimo utraty państwowości przez okres ponad stu lat.

$\mathrm{Z}$ historii polskiego narodu Trump przypomniał postaci znane w świecie, jak Mikołaj Kopernik, Fryderyk Chopin i Jan Paweł II. Tę prezentację najsławniejszych Polaków amerykański prezydent podsumował wyrazami zachwytu nad duchem polskiego narodu, będącym inspiracją dla Amerykanów oraz źródłem nadziei na zwycięstwo dobro nad złem: „Dla Amerykanów Polska zawsze była symbolem nadziei od zarania dziejów naszego narodu. Polscy bohaterowie i amerykańscy patrioci walczyli ramię w ramię w trakcie naszej wojny o niepodległość oraz w wielu późniejszych wojnach".

W dalszej części przemówienia amerykański prezydent podkreślił szacunek, jakim oba narody darzą się wzajemnie, dając temu wyraz chociażby w pomnikach postawionych tym, którzy po dwóch stronach Atlantyku bronili ludzkiej wolności. D. Trump przypomniał, że nieopodal Białego Domu stoją pomniki Kazimierza Pułaskiego i Tadeusza Kościuszki. Z kolei w Warszawie stoi pomnik Ronalda Reagana, a nazwy ulic przypominają o Jerzym Waszyngtonie.

Amerykański prezydent przypomniał, że „W 1920 roku, w bitwie zwanej Cudem nad Wisłą, Polska zatrzymała sowiecką armię dążącą do podboju Europy". D. Trump nie powstydził się właśnie takiej interpretacji tych wydarzeń, a następnie przypomniał o przymierzu nazistowskich Niemiec i komunistycznego Związku Radzieckiego, którego skutkiem była napaść obu krajów na Polskę w 1939 roku. Amerykański prezydent przypomniał światu hekatombę na polskim narodzie ze strony Niemiec i Związku Radzieckiego. „Pod podwójną okupacją naród polski przeżył nieopisaną gehennę: zbrodnię katyńską, Holokaust, warszawskie Getto i Powstanie w Getcie, zniszczenie pięknej stolicy i zagładę prawie jednej piątej ludności". Kreśląc bardzo interesującą panoramę historyczną, D. Trump nie omieszkał wspomnieć, że przez ponad czterdzieści lat Polska i inne zniewolone narody Europy opierały się narzuconym 
komunistycznym rządom, których celem było zniszczenie wolności, wiary, tożsamości, słowem - wszystkiego, co stanowi o istocie kultury i człowieczeństwa. D. Trump wskazał wpływ wiary w Boga na procesy społeczne, przypominając wydarzenie, które zainicjowało polityczne przeobrażenia w świecie:

I kiedy nadszedł dzień 2 czerwca 1979 roku i gdy na Placu Zwycięstwa na pierwszej mszy z polskim papieżem zgromadził się milion Polaków tego dnia każdy komunista w Warszawie musiał zdawać sobie sprawę, że opresyjny system wkrótce się załamie. Zrozumieli to dokładnie w tym momencie, gdy podczas kazania papieża Jana Pawła II milion Polaków mężczyzn, kobiet i dzieci - podjął modlitwę. Nie prosili o bogactwa. Nie prosili o przywileje. Słowami pieśni wypowiedzieli trzy proste słowa: „My chcemy Boga”. Tymi słowami naród polski przywoływał obietnice lepszej przyszłości. Polacy odnaleźli w sobie nową odwagę, by przeciwstawić się prześladowcom. I odnaleźli słowa, by zapowiedzieć, że Polska znów będzie Polską. Kiedy stoję tu dzisiaj przed tym pełnym wiary narodem wciąż słychać tamte powracające echem głosy. Niosą przesłanie, które dzisiaj jest równie prawdziwe jak dawniej. Naród polski, naród amerykański i narody Europy wciąż wołają: „My chcemy Boga”. Razem z papieżem Janem Pawłem II, Polacy umocnili swoją tożsamość jako naród poświęcony Bogu. I za sprawą tej dobitnej deklaracji, kim jesteście, zrozumieliście co należy uczynić. [...] I wygraliście. Polska zwyciężyła. Polska zawsze zwycięży! ${ }^{28}$

Po nakreśleniu bohaterskiej historii zmagań polskiego narodu o wolność i zachowanie chrześcijańskiej tożsamości, D. Trump wymienił kilka współczesnych zagrożeń dla ludzkiej cywilizacji i wskazał na konieczność pielęgnowania pamięci i tożsamości. Niejako odwracając znaną negatywną wypowiedź Jana Pawła II o tym, „że giną narody, które tracą pamięć”, D. Trump wyraził tę samą myśl pozytywnie. Mówił: „Dopóki wiemy, skąd przyszliśmy, dopóty wiemy, dokąd zmierzamy”.

Na przykładzie Polski 45. prezydent Stanów Zjednoczonych wskazał, że $\mathrm{w}$ historii istotna jest wola przetrwania narodu. Stawiał retoryczne pytanie, czy Zachód ma taką wolę przetrwania. Po retorycznych pytaniach nastąpiła konkluzja wskazująca, jak ważne dla trwania cywilizacji jest pielęgnowanie tradycyjnych wartości: „Na nic zdadzą się największe gospodarki świata i broń największego rażenia, jeśli zabraknie silnej rodziny i solidnego systemu wartości. [...] Nasza walka w obronie Zachodu nie zaczyna się na polu bitwy - zaczyna się od naszych umysłów, 
naszej woli, naszych dusz [...]. Nasza wolność, nasza cywilizacja i nasze przetrwanie zależą od tych właśnie więzi historii, kultury i pamięci”.

Przemówienie D. Trumpa zostało zwieńczone podsumowaniem pełnym nadziei $\mathrm{w}$ to, że jak nie udało się zniszczyć polskiego narodu, nie uda się też zniszczyć cywilizacji zachodniej. W ostatniej sentencji znalazło się jeszcze wezwanie słuchaczy do kulturowej walki o rodzinę, wolność, Ojczyznę i o Boga, oraz typowe dla podniosłych przemówień amerykańskich prezydentów końcowe życzenie: „Niech Bóg błogosławi Naród Polski”.

\section{Obraz Jana Pawła II i Polski}

Jan Paweł II jest Polakiem, który w całej historii narodu rozsławił go najbardziej na świecie. Zawsze się przyznawał do swojej tożsamości. Spuścizna doktrynalna jego pontyfikatu jest jedną z najbogatszych w historii Kościoła: obejmuje 14 encyklik, 15 adhortacji apostolskich, 11 konstytucji apostolskich, 45 listów apostolskich, a także setki katechez wygłoszonych podczas generalnych audiencji oraz homilii głoszonych podczas sprawowania Mszy św. i innych nabożeństw. Widziały go miliardy ludzi na świecie. Część z nich czerpała od niego - z jego myśli i świadectwa życia - inspirację do odnowienia wiary w Chrystusa oraz motywację do kształtowania świata w duchu Ewangelii. Zaledwie dziewięć lat po śmierci został zaliczony w poczet świętych Kościoła ${ }^{29}$. Jan Paweł II był i pozostaje chlubą polskiego narodu i Kościoła. Ze wszech miar słuszne jest pielęgnowanie jego dziedzictwa zarówno w Stanach Zjednoczonych, jak i w Polsce, zwłaszcza z okazji okrągłych rocznic urodzin, śmierci, wyboru na Stolicę Piotrową, beatyfikacji czy kanonizacji. Jan Paweł II jest najlepszym przykładem tego, co najpiękniejsze w polskim narodzie.

Przypomniane przemówienia prezydentów Stanów Zjednoczonych stanowią przykład dowartościowania najwybitniejszego Polaka w dziejach narodu, jakim był Jan Paweł II, a także samego narodu polskiego. Jak zauważyli prezydenci Stanów Zjednoczonych, zarówno Jan Paweł II, jak i naród polski odegrali ważną dziejową rolę w historii świata. Mieli i mają też niemały wpływ na kształt najbardziej pluralistycznego społeczeństwa na świecie, jakie tworzą obywatele Stanów Zjednoczonych Ameryki.

29 Saint John Paul II National Shrine. Plan Your Pilgrimage, https://www.jp2shrine.org/ jps/en/resources/plan-your-pilgrimage-booklet.pdf (dostęp: 9.07.2020). 
W obu przeanalizowanych przemówieniach dowartościowana została żywa w narodzie wiara w Boga, będąca inspiracją do przeobrażeń społecznych. W obu też krytycznie oceniony został komunizm narzucany Polakom przez imperialną Rosję. Ponadto wyeksponowane zostały godne promowania takie wartości jak: godność osoby ludzkiej, obrona życia na każdym etapie jego rozwoju, gotowość do przebaczenia i pojednania, dążenie do poznania prawdy, połączone z tolerancją. Tym, co różni przebadane przemówienia, są inaczej rozłożone akcenty, co wynika z okoliczności, w jakich zostały one wygłoszone. Przemówienie G.W. Busha jest bardziej skoncentrowane na osobie i osiągnięciach Jana Pawła II jako przedstawiciela narodu polskiego. Natomiast przemówienie D.J. Trumpa było skoncentrowane na historiozofii polskich dziejów, w której Jan Paweł II odegrał szczególnie ważną rolę.

Przeprowadzone badania mają bardzo zawężony zakres. Mogą służyć jako inspiracja do dalszych analiz porównawczych nad percepcją osoby i dzieła Jana Pawła II oraz narodu polskiego przez przywódców Stanów Zjednoczonych.

\section{Zakończenie}

Poddane analizie przemówienia wykazały, że zaprezentowani prezydenci amerykańscy mieli świadomość, iż miliony Polaków przyczyniły i nadal przyczyniają się do budowania duchowego i materialnego dobrobytu ich kraju. Głosu Polaków nie można lekceważyć ani po jednej, ani po drugiej stronie Atlantyku. Polacy okazali się lojalnymi sojusznikami Ameryki zarówno w burzliwych okresach historii obu narodów, jak i w czasie ostatnich konfliktów międzynarodowych po zamachach terrorystycznych z 11 września 2001 roku. A najsławniejszy z Polaków, święty Jan Paweł II, w czasie swojego ponad dwudziestosześcioletniego pontyfikatu zyskał niekwestionowany autorytet moralny na świecie i jak nikt inny rozsławił swój naród. Jego słów słuchali uważnie przywódcy światowych mocarstw. Był głosem ludzi pozbawionych głosu. Konsekwentnie bronił ludzkiego życia od poczęcia do naturalnej śmierci. Upominał się o godność i wolność każdego człowieka. Podkreślał, że podstawą tej wolności jest wolność religijna. Fascynował oryginalnością, męstwem, wrażliwością na drugiego człowieka, otwartością i poczuciem humoru. 


\section{Bibliografia}

\section{Książki i monografie}

Burghardt Walter J., Preaching. The Art and the Craft (New York-Mahwah: Paulist Press, 1987).

Bush George W., A Portrait of My Father (New York: Random House, 2014).

Bush George W., Decision Points (New York: Random House, 2010).

Bush George W., Out of Many, One: Portraits of America's Immigrants (New York: Crown Publishing Group, 2021).

Jaroszyński Czesław, Jaroszyński Piotr, Podstawy retoryki klasycznej (Szczecinek: Fundacja Nasza Przyszłość, 2008).

Korolko Mirosław, Sztuka retoryki. Przewodnik encyklopedyczny (Warszawa: Wiedza Powszechna, 1990).

Legutko Ryszard, Antykaczyzm (Kraków: Wydawnictwo M, 2013).

Bush George W., Portraits of Courage: A Commander in Chief's Tribute to America's Warriors (New York: Random House, 2017).

Weigel George, Świadek nadziei. Biografia papieża Jana Pawła II (Kraków: Znak, 2005.

Wielkie mowy historii, t. 1-4, red. Marek Gumkowski (Warszawa: Wydawnictwo Polityka, 2006).

\section{Źródła internetowe}

Amy Coney Barrett ist US-Verfassungsrichterin! - Senat bestätigt die Kandidatin, http://kath.net/news/73255 (dostęp: 27.10.2020).

Bush George W., Selected Speeches of President George W. Bush 2001-2008, 37-39, https://georgewbush-whitehouse.archives.gov/infocus/bushrecord/ documents/Selected_Speeches_George_W_Bush.pdf.

Bush George W., Office of George W. Bush: https://www.georgewbush.com/ (dostęp: 10.10.2020).

Duignan Brian, Donald Trump, president of the United States, https://www.britannica.com/biography/Donald-Trump (dostęp: 10.10.2020).

Duignan Brian, George W. Bush, president of the United States, https://www. britannica.com/biography/George-W-Bush/Presidency (dostęp: 10.10.2020).

Masny Ignacy, Jan Paweł II wobec wojny w Iraku w 2003 r., https://jp2online.pl/ publikacja/john-paul-ii-on-the-2003-iraq-war;UHVibGljYXRpb246OTg= (dostęp: 2.10.2021).

Saint John Paul II National Shrine. Plan Your Pilgrimage, https://www.jp2shrine. org/jps/en/resources/plan-your-pilgrimage-booklet.pdf (dostęp: 9.07.2020).

Supreme Court of the United States. Current Members, https://www.supremecourt.gov/about/biographies.aspx (dostęp: 27.10.2020).

Theodore Edgar McCarrick, http://www.catholic-hierarchy.org/bishop/bmccar. html (dostęp: 9.07.2020). 
Trump Donald, Remarks by President Trump to the People of Poland (July 6, 2017), https://www.whitehouse.gov/the-press-office/2017/07/06/remarks-president-trump-people-poland-july-6-2017 (27.10.2020), https://trumpwhitehouse.archives.gov/briefings-statements/remarks-president-trump-people-poland/ (dostęp: 8.04.2021).

US-Ordensfrauen bei Trump-Wahlkampf in Ohio, http://kath.net/news/73242 (dostęp: 26.10.2020). 